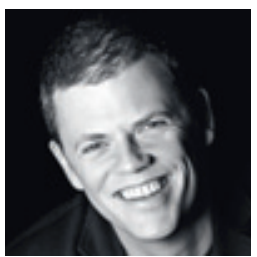

Are Kalvø

Forfatter

\title{
Sjuk jul!
}

\section{Det finaste med juleferien er å bli sjuk.}

Det er lenge sidan den første gongen eg høyrde nokon hevde at det er i feriar at folk verkelig blir sjuke. Eg veit ikkje om det er sant. Og om det er sant, så veit eg ikkje kvifor det er slik. Eg reknar med at det har noko med tid å gjere. Resten av året er det så mykje. Det er barn som skal hentast og møte som skal planleggast og presentasjonar som skal førebuast og konferansar som skal besøkast og papir som skal lesast og spagetti som skal kokast og førtiårskriser som skal haldast nede, og då har ein gjerne ikkje så mykje tid att til å kjenne etter korleis ein har det.

Før ferien kjem.

Då er det ingen møte som skal hentast og konferansar som skal lesast og barn som skal planleggast. Då har ein tid til å berre sitte i ein stol, for eksempel, heilt stille, og kjenne etter. Og då kjem det. Ei svak murring her, litt stikking der, små rykningar, sveittetokter. Når du går for å hente deg litt kaffi, merker du for første gong at du dreg litt på den eine foten. Når du sett deg ned igjen, kjenner du at du er sliten. Temperaturen stig, sveitten driv. Du blir trøytt. Alt dette kan skuldast at det er varmt heime og akevitt til maten og mykje reprisar på tv. Men det kan vere noko anna også. Det kan vere ekte sjukdom.

$\mathrm{Eg}$ har bestemt meg for å gjere maksimalt ut av feriane. Og spesielt juleferien. I andre feriar er det ikkje sikkert ein rekk å vere sjuk. Då skal det gjerne reisast. Då er det slott som skal avbildast, strender som skal liggast på, museum som skal besøkast, suvenirar og amerikanarar som skal latterliggjerast og impulsar ein skal ta til seg. Det blir omtrent som resten av året, med konferansar som skal hentast og papir som skal kokast og møte som skal haldast nede.

Derfor veit eg kvart år at juleferien kan vere den sjansen eg har i år til å vere skikkelig sjuk. Så derfor vil eg gjerne få litt ut av det. Prøve litt ulike sjukdommar. Kanskje nokre nye og eksotiske sjukdommar, til og med. Det er viktig å ha noko spennande å snakke om når ein kjem tilbake på jobb etter ferien.

Med ein gong juleferien tek til, set eg meg rett ned i ein stol og konsentrerer meg hardt om å kjenne meg dårlig. Eg veit at eg ikkje har så mange fridagar før ferien er over, så det gjeld å bli så sjuk som mulig før kvardagen kjem tilbake med press og mas om presentasjonar som skal møtest og spagetti som skal hentast og barn som skal kokast.

I fjor jul gjekk eg verkelig inn for å kjenne meg sjuk. Allereie etter eit kvarter begynte eg å hoste og kjenne meg svimmel. Ei veke seinare hadde eg fått ein sjukdom eg ikkje eingong ante eksisterte. Då kjenner ein at ein verkelig har fătt noko ut av juleferien. Og ein vender tilbake til jobb etterpå og kjenner seg friskare enn nokon gong, og klar som eit egg til å koke møte og halde nede konferansar og presentasjonar.

Det er ikkje alle som har det sånn. Det finst folk som jobbar meir enn meg. Folk som jobbar skikkelig mykje. Dei har sannsynligvis aldri ein heil ferie til å bli sjuke. Dei har kanskje berre éin dag her og éin dag der. Då må dei henge i å bli sjuke. Og tenk på dei som er på jobb nesten heile tida, og må legge inn ørsmå sjukdomsutbrot $\mathrm{i}$ ledige stunder i løpet av arbeidsdagen. Ein kjapp lungebetennelse medan den innleigde foredragshaldaren slit med å få videokanonen til å verke. Eit lett anfall medan skrivaren varmar seg opp. Det verkar stressande. Ein blir utsliten av slikt. Men det har ein jo ikkje tid til.

Ein får vere takksam, som har nokre feriar å bli sjuk i.

Det ideelle må vere å ikkje ha jobb, og vere litt sjuk heile tida. Då slepp ein stresset med å bli sjuk i ferien og halde seg frisk resten av året. Tenk på dei som har det slik. Dei har det godt, dei. Som å ha litt jul heile tida. Berre åleine og utan pakkane og alt det andre.

Det hadde vore noko.

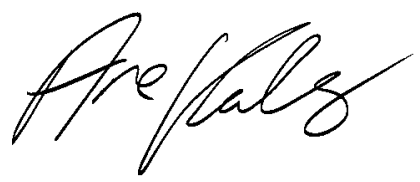

\section{I neste nummer:}

Intensivmedisin

Seponeringsreaksjoner

Cervikalcolumna
Melanommetastaser

Spirometri

Lungekreft 